\title{
Local Struggle for Accessing State Forest Property in a Montane Forest Village in Java, Indonesia
}

\author{
Ahmad Maryudi ${ }^{1} \&$ Max Krott $^{2}$ \\ ${ }^{1}$ Faculty of Forestry, Universitas Gadjah Mada, Indonesia \\ ${ }^{2}$ Forest and Nature Conservation Policy, Georg-August Universitaet Goettingen, Germany \\ Correspondence: Ahmad Maryudi, Faculty of Forestry, Universitas Gadjah Mada, Jln. Agro No.1 Bulaksumur \\ Yogyakarta 55281, Indonesia. Tel: 62-274-550-541. E-mail: maryudi76@yahoo.com
}

Received: May 5, 2012 Accepted: May 30, 2012 Online Published: June 15, 2012

doi:10.5539/jsd.v5n7p62

URL: http://dx.doi.org/10.5539/jsd.v5n7p62

\begin{abstract}
How local people can access state forests has become a central issue in forest resource management in Indonesia in recent years. This is because for most of the 'modern history' of forest management in the country, the forest resources have been at the monopoly of the state. In fact, there have been an increasing number of local people' struggles for obtaining meaningful and legal access to the state forest resources in the country. In response to these, the forest administration has implemented a community forestry program. This paper aims to observe the transformation the people's access to the forests, whether the community forestry program improve the access to the state forest resources. Employing the theory of access provided by Ribot and Peluso (2003), which defines access as the ability to benefit from a resource either legal or illegal, this paper finds that the community forestry program actually reduces the people's access to the forests.
\end{abstract}

Keywords: access, local people, state forest, community forestry

\section{Introduction}

How local people can access the state forests has become a central issue in forest resource management in Indonesia in recent years. This is because for most of the modern history of forest management in the country, the forest resources have been at the monopoly of the state, prohibiting local people to use and access the resources (Peluso, 1992; Barr et al., 2006). Nonetheless, access to the forests by local people is not uncommon, albeit the illegal label from the state agencies. In fact, there has been an increasing number of spontaneous and organized local people struggles for obtaining meaningful and legal access to the state forest resources over the past decade (see Adi et al., 2004; Wulan et al., 2004; Nomura, 2008; Peluso, 2011).

This paper analyzes how the local people of Benowo, a village at the top of Menoreh Hills in Central Java, Indonesia, pursued legal access to the state forestland administered by the state forest enterprise of Perhutani (Note 1). The state forest in the village is under the management of Kedu Selatan (Purworejo) Forest District. In response to the people's interests, the forest office offered a community forestry program of Pengelolaan Hutan Bersama Masyarakat (PHBM). The program was nationally launched in 2001 as a generic model for the whole state forests in Java. It aims to integrate socio-economic community development in forest management system from which they can obtain economics benefits for improving the welfare and quality of life. PHBM defines rights and responsibilities of each parties regarding how the state forests managed and used. More importantly, the program defines the degree to which the people and their group are allowed to access the forests. This paper particularly aims to observe the transformation of the people's access to the forests. What does the community forestry mean for the local people? Does it improve access to the state forest resources?

To answer the questions, this paper borrows Ribot and Peluso's theory of access (2003), which distinguishes access as "a bundle of power", from property as "a bundle of rights". Ribot and Peluso (2003) expand the theories of property rights (for instance of MacPherson, 1978) which only involve a bundle of decision rights involving a resource. Ribot and Peluso (2003) argue that the theory of property rights generally focus on the 'rights' - socially acknowledged by law, custom, or convention-, to use and to benefit from a resource, as well as to exclude others to do the same. They nonetheless note that the lack of control over the property often leads a situation where those do not possess the property rights can still enjoy the resource (a similar view held by 
Stebek, 2011).

Therefore, Ribot and Peluso (2003) see the importance to add the notion of power of access, which is they define as the ability to benefit from a resource, either legal or illegal. Based on their definition, this paper argues that the community forestry program otherwise reduces the people's access to the forests to a certain degree. To elucidate the argument, this paper is carefully structured as follows. First, it briefly outlines the centralistic control in forest management in Java that gives the ownership of the forests to the state. The rest of the paper deals with the ability of the people to benefit from the forests before and after the commencement of the community forestry program.

\section{A Brief Overview on Forest Administration in Java}

Like in many countries that experienced with a colonial power (Webb, 2008), the model of forest administration in Java duly follows the notion of state control over 'waste' land and forests laid during the colonial time (Thorburn, 2004). The argument and justifications rests on the development discourse that the management of the forests has to serve "the interests of the whole country" so that the state is then monopolizing the uses and access (Barber, 1998). A bulk of scientific publications has been dedicated for explaining the centralistic forest control in Java. Peluso in particular has described the centralistic forest traditions at a great length that are centered on control over the state's forestland and the resources as well as the activities by local people in the forests (Peluso, 1991; 1992; 1993a; 1993b; 2011; Peluso \& Poffenberger, 1989). Even, the current forest administration - the state forest enterprise of Perhutani - is argued to exert more stringent control than the colonial administration as it adds the notion of patronage and patrimonialism to the bureaucratic management (Peluso \& Poffenberger, 1989).

One of the core elements of the centralistic control in Java's forest management is the possession of forestland used as the foundation to capture the most benefits from the forests (Peluso, 2011). Since the colonial time, forestland as the property of the forest administration has been clearly delineated and distinguished from agricultural land of private ownership (Peluso, 2011). In many instances, the forest delineation was preceded with the 'removal' of enclaved communities which were seen as detrimental to the forest management (see Peluso \& Vandergeest, 2001). Long-term and intensive activities by peasant farmers in the forest is therefore deemed as threatening 'forest interests' since they could eventually mimic agricultural activities on private land (Maryudi, 2011). In addition, the management practices in Java's forests are characterized as "scientific forestry", a body of forest knowledge and practices (Peluso, 1992) favoring commercial monoculture plantations with the emphasis on industrial raw materials such as sawmill timber and pulp with the suppression of undesired species (Klooster, 2002). The forest practices center on the application of technical measures such as site productivity, tree increment and the optimum cutting ages, as well as the control on the harvest (Nelson, 1998; Farrel et al., 2000).

Further, the name of the scientific forestry with centralistic control in Java is the monopoly on the forest uses by the state that effectively prevent local people to access the forest resources. In fact, forest dwellers are only permitted to have temporal access - two years from the reforestation- on forestland for agroforestry practices and collect non-timber forest products (Peluso, 1993b). The agroforestry practices rarely satisfy the basic daily need, instead of a supplement for the yield from the limited yield from the private land (Peluso, 1993b; Maryudi, 2011). Either, non timber forest products are limited in terms of number and variety due the nature of monoculture plantations (Peluso, 1993b; Maryudi, 2011). In many ways, subsistent uses by local people are often viewed as a threat for the forest management (Peluso, 1993b). Uses and access outside the direction of the forest offices are usually confronted with "the goals of the state" and therefore deemed as illegal (Barber, 1998; Webb, 2008).

\section{The Struggles for Forest Access in Benowo Village}

As said, Benowo Village lies on the very top of the Menoreh Hills, with extreme terrains. The humid climate with heavy rainfalls makes the environment hospitable for agricultural crops both seasonal and perennial. The village itself is characterized by a small track of un-irrigated paddy-fields and tree gardens, with monoculture pine (Pinus merkusii) plantations owned by the state also scattered within. Literatures have extensively discussed the challenges faced by the rural farmers of Java to sustain their daily livelihood owing the limited possession of agricultural land (Lindayati, 2000; Bratamihardja et al., 2005; Peluso, 2011); this is also seen in Benowo village. Shading more doubt, most of the private land is planted with perennial crops, mostly cloves harvested approximately every four or five years. It was advised during the research that many of the people sporadically work in the cities for casual jobs, even permanently leave the village to find better life conditions. Those staying in the village, as cases in regions surrounded by with the state's pine plantations, work as a casual labor of carrying (buruh pikul) pine resin from the forest to the landing before it is transported to the processing industry 
(Peluso, 1993b; Colfer et al., 2008).

For decades, the people have intensively cultivated the state forestland, both production and non-productive forestlands, with seasonal and perennial agricultural crops such as cloves, coffee, cacao, Parkia speciosa, Gnetum gnemon as those species grow well in the montane areas (Suara Merdeka, 14 September 2006). In some parts of the state forests within the village, the agroforestry visibly replaces the monoculture pine forests. While the limited possession of private land plays the major drive on occupying the state forestlands, there have been also claims from the people that some parts of the state forests lands were of their ancestors appropriated during the colonial forest administration (Suara Merdeka, 14 September 2006). While prohibited, the people keep practicing the agroforestry although they have to deal with the forest rangers patrolling the forests. It was reported that the people used to provide some bribes - a portion of the sales of the products- to the forest rangers so that they can continue their activities in the forests (Jakarta Post, 31 March 2006). With the continued occupation, monoculture reforestation became less successful in many state forest compartments. While the pine is visibly non-existent, the forest office eventually classified the occupied forestland as non-suitable for (pine) production (Tidak Baik untuk Produksi). Such legitimated the informal control of the people's over the forestland.

Approaching the end of the last millennium- catalyzed by the downfall of authoritarian regime ruling the country- the struggle for forest access has become more visible. Aside from the tenurial claim on some of the state forestlands, the people show their anger toward the monoculture of pine. It was said that over the past decade, the people of Benowo have been experiencing water shortages. They link the problem with the pine, which is perceived to being a "thirsty species" (Suara Merdeka, 14 September 2006). Although Perhutani continuously argues the contrary -with including scientific research findings from hydrologists (for instance see Soejoko et al., 1998; Manan et al., 1999), the perception continues. It was said that conflicts between the people over water resources have been more frequent. In the meantime, the village chief is seeking support from the neighboring villages whether they have also faced such problems. The general feeling is that the monoculture pine is the root of the problem. While the issues on water shortages have acquired a solid ground, they were apparently exploited to justify the people's efforts to access the state forestland, principally the agroforestry practices.

The early 2004 saw the village committees of Benowo village with of the neighboring villages created an inter-village cooperation body (Lembaga Kerjasama Antar Desa) to discuss their concerns on water shortages and related problems. Curiously, the concerns were then expanded to the perceived limited contributions of the management of the state forests to the development of their villages. The cooperation body was expected to link local economic development and the management of the state forests, with the view on income generations from the state forests for supporting the development of the villages (Utami, 2005). The establishment of the cooperation body was to some degree driven by the decentralization policy of forest resources to local government authorities earlier mentioned (Utami, 2005). While the discontent toward the forest office became more apparent, the forest office appeared to still see little threat and to discount the local movements.

\section{Legal Access through Community Forestry}

However, the dynamics of the local politics changed considerably when a local NGO-named Yayasan Mastaapproached the people of Benowo to assist them in the pursuit of having more access to the state forests. The NGO was making the people aware of PHBM community forestry program the state forest company has launched. It was still unclear how the people of Benowo did not get some knowledge on the community forestry program, which was started four years prior Masta's arrival. Curiously, it was the strategy of the district forest administration in dealing with the local struggles in that the office was reluctant to collaborate with the people in managing the forests. With the perceived threat borne by Yayasan Masta in mind, the district forest office bypassed the NGO by convening a 'socialization' of its community forestry in Benowo village and expected the people to get involved in the program.

The people were then asked to organize themselves within a formally registered forest user group (locally called Lembaga Masyarakat Desa Hutan/ LMDH) for the implementation of the program. In many cases, the forest office usually provides the necessary assistance for local communities in dealing with legal requirement of a formally registered group (see Maryudi, 2011). The village committees of Benowo instead opted to work with Yayasan Masta in creating the group, named LMDH Sari Bumi Makmur. This to some extent highlights the political directions the people of Benowo later wish to pursue with the clear aims on challenging the forest office. The name of the group also mirrors some of their political aspirations; according to the chief of the group it refers to one of the sub-villages (hamlet) of Benowo whose residents were forced to migrate as the land was 
gazetted as state forestland. The ensuing events of the socialization from the forest office on the community forestry program have seen the more encroachment/ occupation on the state forestland, not only on the non-productive compartments but also on the productive areas due the ill-advised from the forest rangers that the program allowed the people to use the forests for agriculture cultivation. They planted the productive areas with their preferred species, both perennial and seasonal so that the areas resembled the 'non-productive', mentioned earlier.

Despite the tensions between the forest office and the village elites, in 2006 PHBM community forestry was formally implemented in Benowo village. The district forest office expected that the local struggles for more access to the state forests would eventually decrease as the village chief on behalf of the people had signed an agreement containing rights and responsibilities of each parties regarding how the state forests managed and used. More importantly, the agreement defines the degree to which the users and the group are allowed to access the forests. Drawing from several cases, Maryudi and Krott (2012) suggest that in PHBM community forestry local people are only permitted to collect minor products. In fact, the degree of legal access to the forests by the people remained it was once in that the people are only permitted to have temporal access on forestland for agricultural cropping as well as collecting non-timber products (Djajanti, 2006; Maryudi, 2009). The challenge for the people in cultivating seasonal crops lies on the dense pine stands which limit the sunlight that reaches the forest floor that eventually creates unfavorable environment for the planting. While the forest office rarely carries out forest thinning which has been planned, the people sporadically thin the dense forests (see Maryudi, 2011).

More importantly, the forest office requires the group committees to control the activities in the forests that the people have to abandon the illegal practices (Maryudi \& Krott, 2012). With the new mode of control through the group committees, the ability of the people to access the forests decreases to some degree. The people expect to maintain the agroforestry which has been well developed in the village. If fact, those aspirations have not been clearly satisfied in the community forestry agreement. The forest office insisted that such practices need to be separately regulated, including how the benefits are shared with the forest office (Dwi Wicahyono, Chief of Forest District, October Interview 2006). Further, the people need the wider spaces between the forest species to plant both perennial and seasonal crops for ex-harvest compartments. This initially received strong opposition from the forest office, which perceived the request would compromise the number of pines planted that eventually compromise the company's profits from the forests.

Indeed, Perhutani introduces a benefit sharing scheme in PHBM community forestry; that the participating groups - when their contribution in reforestation, forest nurtures and patrol deemed as sufficient - are to be rewarded with some cash from the sales of main forest products, in this case pine resin and timber from final harvests, respectively $5 \%$ and $25 \%$ from the sales (Note 2 ). Initially, the benefit sharing scheme was initially lauded as one of the major improvements in the forest practices in the country as there were no such schemes prior to the community forestry (Kusumanto \& Sirait, 2000; Lindayati, 2000; Djamhuri, 2008). Nonetheless, it comes into the spotlights of sharp criticisms - particularly how the share is defined (Affianto et al., 2005). Even, the community forestry is deemed as exploiting forest dwellers expecting their active participation in forestry activities with marginal returns to them (Maryudi, 2009).

In fact, there have been few sporadic cases of the meaningful 'cash-splash' given the limited final harvests in the forests (Maryudi, 2011). Similar to the case of Benowo, as suggested by the group committees, the cash the group has received is still far below they have initially imagined. The committees further indicated that the district forest office "play with" the calculation by citing there have been no significant changes in the annual shares received despite the sharp increase of resin production from the community forests. There have been some claims that the forest officers working in the field intentionally downgraded the resin quality to keep the share lower than it should have been resulting in the low calculation of the market prices (Khamid, LMDH secretariat, interview on 12 November 2008). Further, speculations continued to circulate that some of the resin production from the forests was reported as of one of the neighboring community forests, this is strongly denied by the forest office and the neighboring villages' chief since the borders of the respective community forests have been clearly delineated (see Maryudi, 2011). While the group committees appear to recreate the fights against the forest office, they start to let forest infringements to occur. They suggested that cases of illegal activities are quite frequent. In addition, the locals sporadically carry out illegal thinning and cutting the dense pine to allow sunlight reaches the forest floor to fostering the growth of agricultural commodities. This suggests that PHBM community forestry is yet to fully satisfy local needs. 


\section{Conclusions}

The case of Benowo has provided some learning curves for the implementation of such socially-minded forest programs as community forestry. Over the past few decades, community forestry has been promoted as one of the promising strategies to promote sustainable forest management with the emphasis of active participation of forest dwellers (Kellert et al., 2000; Blaikie, 2006). The concept of the program centres on how local communities influence the decision making procedures over the forests including the rules of access and the disposition of products (McDermott \& Schrekenberg, 2009; Maryudi et al., 2011). Literatures have extensively discussed whether the program fulfils the high expectation on sustainable forestry heavily depends on the articulation of the local needs (e.g. McKean, 2000; Varughese \& Ostrom, 2001; Agrawal, 2002; Gautam \& Shivakoti, 2005). Numerous cases across the globe have shown that the limited success of community forestry program stemmed from the reluctance of the state agencies to provide better access to local people. The case of Benowo has also revealed that the locals continued to oppose the pre-defined community forestry program because the limited access to the forest. In fact, the ability of the people diminishes as due to the technical rationales of the community forestry. When the (legal) access does not improve, the likely trajectory is that the locals are to continue the illegal activities used to be practiced. It is possible when the mechanisms of control through the community forestry fail to work as the people might not see it necessarily to abide the agreement in the community forestry. Under such a case, the goals of sustainable forestry remain hanging in the balance. Therefore, the forest office needs to genuinely provide the people with improved access to the forests.

\section{Acknowledgements}

The first field research in October-November 2006 was funded by the Faculty of Forestry, Universitas Gadjah Mada, Indonesia. The follow up visits in December 2008 and November 2009 were supported by German Research Foundation (Deutsche Forschungsgemeinschaft/ DFG). The preparation of this manuscript was made possible with the financial support from the Directorate General of Higher Education (DIKTI) of the Ministry of National Education of the Republic Indonesia under the Program Academic Recharging (PAR) 2011 conducted in the Chair of Forest- and Nature Conservation Policy, Georg-August Universität Göttingen (Germany) between October-December 2011.

\section{References}

Adi, N. J., Arganata, F., Chehafudin, M., Fuad, F. H., Nugraheni, S. C. A., Sanyoto, R., ... Walpole, P. (2004). Communities Transforming Forestlands, Java, Indonesia. Asia Forest Network, The Philippines.

Affianto, A., Djatmiko, W. A., Riyanto, S., \& Hermawan, T. T. (2005). Analisis Biaya dan pendapatan dalam Pengelolaan PHBM: sebuah panduan penghitungan bagi-hasil. Bogor, Penerbit Pustaka Latin.

Agrawal, A. (2002). Common resources and institutional sustainability. In Ostrom, E., Dietz, T., Dolsak, N., Stern, P. C., Stovich, S., \& Weber, E. U. (Eds.), The Drama of the Commons: Committee on the Human Dimensions of Global Change (pp. 41-86). Washington, DC: National Academy Press.

Barber, C. V. (1998). Forest Resource Scarcity \& Social Conflict in Indonesia. Science \& Policy for Sustainable Development, 40(4), 4-9. http://dx.doi.org/10.1080/00139159809604579

Blaikie, P. (2006). Is Small Really Beautiful? Community-based Natural Resource Management in Malawi and Botswana. World Development, 34(11), 1942-1957. http://dx.doi.org/10.1016/j.worlddev.2005.11.023

Bratamihardja, M., Sunito, S., \& Kartasubrata, J. (2005). Forest Management in Java 1975-1999:Towards Collaborative Management. ICRAFT Southeast Asia Working Paper, No.2005-1, ICRAFT Southeast Asia Regional Office, Bogor.

Colfer, C. J. P., Dahal, G. R., \& Capistrano, D. (2008). Lessons From Decentralization: Money, Justice and the Quest for Good Governance in Asia-Pacific. Earthscan, London.

Djajanti, D. (2006). Managing Forest with Community (PHBM) in Central Java: Promoting Equity in Access to NTFPs. In Mahanty, S. Fox, J., Nurse, M., Stephen, P., \& McLees, L. (Eds.), Hanging In the Balance: Equity in Community-Based Natural Resource Management in Asia (pp. 63-82). RECOFTC, Bangkok and East-West Center, Honolulu.

Djamhuri, T. L. (2008). Community participation in a social forestry program in Central Java, Indonesia: the effect of incentive structure and social capital. Agroforest System, 74, 83-96. http://dx.doi.org/10.1007/s10457-008-9150-5 
Farrell, E., Führer, E., Ryan, D., Andersson, F., Hüttl, R., \& Piussi, P. (2000). European forest ecosystems: building the future on the legacy of the past. Forest Ecology and Management, 132(1), 5-20. http://dx.doi.org/10.1016/S0378-1127(00)00375-3

Gautam, A. P., \& Shivakoti, G. P. (2005). Conditions for successful local collective action in forestry: some evidence from the hills of Nepal. Society and Natural Resources, 18(2), 153-171. http://dx.doi.org/10.1080/08941920590894534

Jakarta Post. (2006). Benowo villagers benefit from forestry program. Retrieved November 7, 2011, from http://www.thejakartapost.com/news/2006/03/31/benowo-villagers-benefit-forestry-program.html

Kellert, S. R., Mehta, J. N., Ebbin, S. A., \& Lichtenfeld, L. L. (2000). Community Natural Resource Management: Promise, Rhetoric, and Reality. Society \& Natural Resources, 13(8), 705-715. http://dx.doi.org/10.1080/089419200750035575

Klooster, D. J. (2002). Toward Adaptive Community Forest Management: Integrating Local Forest Knowledge $\begin{array}{llll}\text { with Scientific } \quad \text { Forestry. Economic } & \text { Geography, }\end{array}$ http://dx.doi.org/10.1111/j.1944-8287.2002.tb00175.x

Kusumanto, Y., \& Sirait, M. T. (2002). Community Participation in Forest Resource Management in Indonesia: Policies, Practices, Constraints and Opportunities. Southeast Asia Policy Research Working Paper, No. 28. ICRAF SE-Asia. Southeast Asian Regional Research Programme, Bogor, Indonesia.

Lindayati, R. (2000). Community forestry policies in selected south-east Asian countries. CBNRM Program Initiative, International Development Research Centre, Ottawa Canada.

MacPherson, C. B. (1978). Property: Mainstream and Critical Positions. Toronto: University of Toronto Press.

Manan, S., Rusdiana, O., Anifjaya, N. M., Wasis, B., \& dan Purwowidodo. (1999). Pengaruh Kelas Perusahaan Hutan Pinus (Pinus Merkusii) terhadap produksi air: Studi Kasus di KPH Tasikmalaya Perum Perhutani Unit III Jawa Barat. Seminar Pengelolaan Hutan dan Produksi Air Untuk Kelangsungan Pembangunan. Perum Perhutani Bekerjasama dengan Yayasan Institut Manajemen dan Teknologi Kehutanan. Jakarta.

Maryudi, A. (2009). To Create Healthy Forests, Put Them in The Hands of People Who Need Them. The Jakarta Globe. $\quad$ Retrieved $\quad$ October $10, \quad 2011$, from http://www.thejakartaglobe.com/opinion/to-create-healthy-forests-put-them-in-the-hands-of-people-who-ne ed-them/320714

Maryudi, A. (2011). The Contesting Aspirations in the Forests - Actors, Interests and Power in Community Forestry in Java, Indonesia. Goettingen University Press, Goettingen.

Maryudi, A., \& Krott, M. (2012). Poverty Alleviation Efforts through a Community Forestry Program in Java, Indonesia. Journal of Sustainable Development, 5(2), 43-53. http://dx.doi.org/10.5539/jsd.v5n2p43

McDermott, M. H., \& Schrekenberg, K. (2009). Equity in community forestry: insights from North and South. International Forestry Review, 11(2), 157-170. http://dx.doi.org/10.1505/ifor.11.2.157

McKean, M. A. (2000). Common property: what is it? What is it good for and what makes it work? In Gibson, C. C., McKean, M. A., \& Ostrom, E. (Eds.), People and Forests (pp. 27-56). London: The MIT Press.

Nelson, R. H. (1998). Rethinking Scientific Management. Discussion Paper 99-07, Resources for the Future, Washington DC.

Nomura, K. (2008). The politics of participation in forest management. A case from democratizing Indonesia. The Journal of Environment and Development, 17(2), 166-191. http://dx.doi.org/10.1177/1070496507312598

Peluso, N. L. (1991). Colonial Forest Management in Java. Forest and Conservation History, April, 65-75.

Peluso, N. L. (1992). Rich Forests, Poor People: Resource control and resistance in Java. Berkeley, CA: University of California Press. http://dx.doi.org/10.1525/california/9780520073777.001.0001

Peluso, N. L. (1993a). Traditions of Forest Control in Java: Implications for Social Forestry and Sustainability. Global Ecology and Biogeography Letters, 3(4/6), 138-157. http://dx.doi.org/10.2307/2997766

Peluso, N. L. (1993b). Coercing Conservation? The Politics of State Resource Control. Global Environmental Change, 3(2), 199-218. http://dx.doi.org/10.1016/0959-3780(93)90006-7

Peluso, N. L. (2011). Emergent forest and private regime in Java. Journal of Peasant Studies, 38(4), 811-836. http://dx.doi.org/10.1080/03066150.2011.608285 
Peluso, N. L., \& Poffenberger, M. (1989). Social Forestry on Java: Reorienting Management Systems. Human Organization, 48(4), 333-344.

Peluso, N. L., \& Vandergeest, P. (2001). Genealogies of the Political Forest and Customary Rights in Indonesia, Malaysia, and Thailand. The Journal of Asian Studies, 60(3), 761-812. http://dx.doi.org/10.2307/2700109

Ribot, J. C., \& Peluso, N. L. (2003). A Theory of Access. Rural Sociology, 68(2), 153-181. http://dx.doi.org/10.1111/j.1549-0831.2003.tb00133.x

Soedjoko, S. A., \& Suyono, D. (1998). Kajian Neraca Air di Hutan Pinus. Makalah Seminar Pengelolaan Hutan dan Produksi Air untuk Kelangsungan Pembangunan, 23 September 1998, Jakarta.

Stebek, E. N. (2011). Conceptual Foundations of Property Rights: Rethinking De Facto Rural Open Access to Common-Pool Resources in Ethiopia. Mizan Law Review, 5(1), 1-40. http://dx.doi.org/10.4314/mlr.v5i1.68766

Suara Merdeka. (2006). Menelusuri Sejarah "Lemah Simpen". Retrieved October 24, 2011, from http://www.suaramerdeka.com/harian/0609/14/ked13.htm

Thorburn, C. C. (2004). The plot thickens: Land administration and policy in post-New Order Indonesia. Asia Pacific Viewpoint, 45(1), 33-49. http://dx.doi.org/10.1111/j.1467-8376.2004.00226.x

Utami, B. (2005). Kesepakatan Pengelolaan Hutan Bersama Masyarakat Desa. Salam, 12, 18-19.

Varughese, G., \& Ostrom, E. (2001). The contested role of heterogeneity in collective action: some evidence from community forestry in Nepal. World Development, 29(5), 747-765. http://dx.doi.org/10.1016/S0305-750X(01)00012-2

Webb, E. L. (2008). Forest Policy as a Changing Context in Asia. In Webb, E. L., \& Shivakoti, G. P. (Eds.), Decentralization, Forests and Rural Communities: Policy Outcomes in South and Southeast Asia (pp. 21-43). New Delhi: SAGE Publication.

Wulan, Y .C., Yasmi, Y., Purba, C., \& Wollenberg, E. (2004). Analisa Konflik Sektor Kehutanan di Indonesia 1997-2003. Center for International Forestry Research. Bogor, Indonesia

\section{Notes}

Note 1. This paper is based on the field research conducted in October-November 2006 and two follow-up visits in December 2008 and November 2009.

Note 2. The share is corrected with a coefficient of rotation of harvested compartment divided by the running year of the agreement. For example: an 30 year old compartment harvested in the $5^{\text {th }}$ year of the agreement, the share received amount to $=(5: 30) \times$ the sales (details see Maryudi, 2011) . 